\title{
A Longitudinal Study of the Dynamics of Giftedness
}

\author{
Diana B. Bogoyavlenskaya \\ Psychological Institute, Russian Academy of Education, Moscow, Russian Federation \\ E-mail: mpo-120@mail.ru
}

\begin{abstract}
Introduction. The paper presents a longitudinal study nearly a half-century long of the dynamics of giftedness from adolescence to maturity. Giftedness is an individual's ability for creativity. The current study postulates that personal creative achievements can be predicted and that individuals' ability to develop activities on their own initiative is the unit of such analysis of creativity. The concept of creativity is revealed through this ability as its mechanism. The ultimate forms of creativity are actions that lose the form of response.
\end{abstract}

Methods. For the purpose of the study, the authors developed a Creative Field technique. This diagnostic tool has certain advantages over other existing tests, as it also measures intelligence according to the learnability criteria. The study was originated in 1970 with a sample comprised of 60 10th grade students of physico-mathematical school № 2 in Moscow. The second stage of the experiment took place in 1976. It employed the new Creative Field technique developed with the use of mathematical content. The third stage of the experiment was conducted during 2002-2003, at which point in time the sample was somewhat reduced due to inaccessibility of a portion of the original participants. The fourth stage of the study of the genesis of giftedness is currently underway (2018-2019).

Results and Discussion. The study produced reliable measures of giftedness in adolescence and maturity and analyzed achievements in participants' professional activities. These results create an objective framework for analyzing the role of the major life events and personality structure in the realization, and either development or regression of giftedness. The results of the experiments confirmed the relevance of the technique and the validity of the method itself. Students, who reached the highest levels of cognition in the experiment, also made significant discoveries in their professional activities.

Conclusion. The main conclusions are as follows: (a) The method of Creative Field has predictive value, (b) The theory developed by authors is productive.

\section{Keywords}

giftedness, creativity, genesis, personality, spiritual values, method, validity, predictive value, development, regression 


\section{Highlights}

- The study confirms that the personality structure with predominance of spiritual values and cognitive orientation determines individuals' creative potential. This kind of personality structure tends to remain stable even under global changes in society. - The study, which has unfolded throughout nearly fifty years, confirmed the positive dynamics in the development of the respondents' professional activity.

- The study findings confirm the theory behind its framework and speak in favor of predictive value of the developed method.

\section{For citation}

Bogoyavlenskaya D. B. A Longitudinal Study of the Dynamics of Giftedness. Rossiiskii psikhologicheskii zhurnal - Russian Psychological Journal, 2018, Thematic Issue 1 (Vol. 15, no. 2/1), pp. 5-18. DOI: 10.21702/rpj.2018.2.1.1

Original manuscript received 02.09.2018

\section{Introduction}

The study of the nature of any phenomenon involves first and foremost determining its function and disclosure of its structure. We consider giftedness as an ability to create, which corresponds to the growing relevance of its identification and development $[1,2,3]$. In our works, creativity is revealed as a result of the development of activity by the subject on his own initiative [4,5]. (This is the disclosure of the concept of "intellectual activity" (IA) used in our earlier works [4]. The structure of this ability is given in the "unit of analysis" (according to L. S. Vygotsky), in which "affect meets intelligence" [6, p. 34]. Intelligence provides mastery of the activity, and in case cognitive orientation is dominant in the personality organization, he develops it further on his own initiative.

The next step in the study of the nature of a phenomenon is the study of its formation and development. A wide range of studies of the origins of giftedness, the ratio of its genetic and environmental conditioning (the role of genetic and environmental factors in the formation of individual differences) showed that the environmental factors are predominant in its formation [7].

The analysis of our results demonstrated that the systematic environmental factors affecting the manifestation of intellectual activity in members of the same family are the effects that reflect the nature of social relations in the society at large [7].

To identify the factors influencing the dynamics of IA during a certain age period, we conducted a series of longitudinal studies, starting from preschool age, of different duration up to 17 years $[8,9,10,11,12 ; 13]$. To identify the impact of social factors that reflect different stages in the life of the country, 
we currently conduct a longitudinal study at the very school where it was also done in the 90s [8].

Before proceeding to the description of the ongoing longitudinal study of the dynamics of giftedness and substantiation of the method of its identification, it is necessary, at least briefly, to present a palette of foreign longitudinal studies of this problem. Having recognized their priority, we would be able to present the productivity of our approach more clearly.

The handbook collected by R. F. Subotnik [14] presents the most well-known works demonstrating the correspondence between the methodology of the longitudinal studies and the central issues of the work with gifted ones. Taken together, these studies examine early indicators of later academic and career achievements and creativity using a variety of detection methods.

The works presented can be differentiated as follows.

1. These are a number of research works based on people who are considered gifted on the basis of previously demonstrated achievements in different fields.

L. M. Terman [15] is a pioneer in the large-scale study of the conditions that determine success of the gifted children in adult life. He made an important conclusion for understanding the phenomenon of giftedness, which states that not only high intelligence, but also personal factors are important for achievements.

According to the results of the 22 years long observation of a sample of 220 students, E. P. Torrance [16] concludes that the presence of a steady interest in the profession and in the mentor are among the five conditions of creative achievements.

He also presented 2 examples of 30 years long study of "Beyonders". A list of the main characteristics that make "Beyonders" unique is compiled, of which the key ones are highlighted: taking pleasure in deep reflection, the love of one's work, the clarity of purpose, taking pleasure in one's work, understanding of one's mission, the courage to be creative [17].

In the article by C. P. Benbow, O. Arjmand [18] which analyzed educational experience of a cohort of 1247 mathematically gifted young men identified in grades $7-8$, after graduation from school and college, identified factors affecting academic achievement: curriculum studied before the college, marital status, attitude to science, differences in the level of talent.

2. These are the results of research on the sample, the participants of which were considered as intellectually gifted based on their test results, forms of leisure or performance on creative tasks. This includes the Munich study, conducted on 26,000 students from 1986-1988 to 1993 [19].

M. A. Runco [20] presented a 20 years long longitudinal study on 2 samples of the gifted ones, equal in ability, but different in the sphere of the talent 
application (average IQ $=155$ ) which allowed to establish a high correlation between the level of divergent thinking and self-sufficiency.

In the Fullerton study [21], children (starting from when they were 1 year olds) and their families were observed every six months in preschool age and annually at the age from 5 to 17 years old. The follow up was conducted at the age of 24 years.

A study of the gifted adolescents from the age from 13 to 33 [22] was conducted by J. Wai, D. Lubinski and C. P. Benbow. During the first phase (sample of 1,243 boys, 732 girls), the possibility of future achievements is assessed. In the second phase (sample of 323 men, 188 women), data from the age 13 are correlated with the level of education at age 23 to predict achievement by the age of 33. These same authors conducted another 2 studies [23]. In the first study they observed 1467 adolescents aged 13 gifted in the field of mathematics during 25 years. The second study retrospectively describes the adolescence of the 714 best graduate students (average age 25 years), and their achievements up to 35 years. In both studies, participants with significant achievements in science, etc., in the past had a more advanced secondary education in these areas.

3. These are longitudinal observations of the gifted people, according to the concepts of giftedness, or multidimensional processes of talent identification not directly related to the accepted theory of giftedness.

The study by K. A. Heller $[24,26]$ is based on a multidimensional concept of giftedness. It considers academic achievements, leisure time, cognitive and motivational factors as well as school and family socialization conditions. The second phase presents an analysis of the results of gifted and other students aged from 6 to 18 years. C. Perleth, W. Sierwald, K. A. Heller [25] have shown that intellectually and creatively gifted people are very different from each other in their achievements.

The review of longitudinal studies of gifted children with the aim of being able to predict their achievements in professional work in the future is based, at best, on their real achievements or the evaluation of their general or special abilities. An adequate level of ability and "achievement motivation" actually can provide insights into the possibility of achievement at the level of common sense without any research. However, the whole practice of testing intelligence has shown that such tests do not reveal the creative ability. A critical analysis of the concept of "creative giftedness", measured by creativity tests, is described in detail in our works [5, pp. 93-150]. The motives are the love for the profession and the understanding the beauty of regularities. However, they are considered at the level of particularities, among many other success factors. The decisive role of the structure of their relationship and contributions is not clear. 


\section{Methods}

Since 1971 we have described the "creative field" method in our works more than once. But today it is the only method built outside the framework of the "stimulus-reaction" model. Due to this reason, it allows real-time experiment identify the inherent ability of a person to develop activities on their own initiative. In fact, as part of the laboratory experiment, it simulates human research activities within a system of similar tasks, which provides a two-layer model of activity. The first - the surface - layer is a given activity aimed at solving specific problems. The results obtained at this level allow us to assess the level of intelligence in all parameters of learning. The second - the deepest - layer, disguised by the "outer" layer and not obvious to the subject, represents the activity of identifying hidden patterns, which constitute the entire system of problems, the discovery of which is not required to solve the given tasks. The presence of this layer makes it possible to record the process of development of the activity conducted on the subject's initiative $[5,26,27]$.

On the basis of the obtained results of diagnostics we created the typology of creative abilities based on the levels of knowledge:

1. Work within the framework of a given activity, with all its possible success, belongs to the stimuli-productive level.

2. The discovery of new regularities, as "the explosion of the layers of existence" by S. L. Rubinstein [29], being a manifestation of creativity, refers to the heuristic level.

3. The theoretical proof of the open pattern belongs to the highest level of creativity - creative (to avoid repetition, the next creative level is named in Latin. The term is not linked with divergence in any way).

\section{Results and Discussion}

The first stage of the experiment

The experiment was conducted in 1970 with the use of one of the variants of the "Creative field" method - "Fabulous chess" [5] on a sample of students of 10th grade from the Moscow school no. 2 which specializes on Physics and Math. All the members passed a serious selection for admission. This was important because testing of the method showed that the ability to develop activities on their own initiative is manifested only in those people who have successfully mastered the proposed activities (approbation of the method took place on samples of 10 students and teachers from $12 \mathrm{MSU}$ departments, the experiment with their participation was conducted weekly for 3 months in 1969). The difficulties in performing the tasks stimulate the search for workarounds. Therefore, one of the principles of the "Creative field" method requires the absence of not only external, but also internal (evaluative) stimuli. 
About $50 \%$ of our students have not only successfully mastered new activities, but also have reached creative levels. Moreover, one of the students surprised us not only with the highest results in our entire sample of students and scientists, but with the modesty of reaction to his achievements. M. G. "worked" in the experiment calmly, on the third problem, slightly slowing down the pace, he explained that he proved the theorem of its solution. Hearing: "Thank you, the experience is over", he pointed to the blank forms. When it was explained to him that many people need more tasks, he was surprised: "Can it really be so? That's what we are taught. If you find a new pattern, you must prove it before you can use it". He was simply bewildered, without a shadow of the triumphant feelings, without a sense of superiority. The rare modesty of a strong student along with a brilliant entry to the highest level in the experiment allowed us to expect extraordinary results from him in the future.

\section{The second stage of the experiment}

The second stage of the experiment took place 5 years later, when the boys graduated from high school. The experiment on this sample was repeated to check the relevance of the new method "coordinate system" by the method of "Creative field" on the mathematical material [28]. And, of course, we included this sample along into the study along with other samples (students of mathematical boarding school at MSU and researchers of IFHT AS of the USSR).

38 out of 60 subjects of the school sample participated in the second stage of the experiment. Other graduates of the school went to universities in different cities and countries.

During the second experiment, we were afraid that 5 years was a short period of time and we would not get "clean" results. Therefore, the experiment was conducted by my graduate student, and I wrote my prognosis of the result before the experiment and sealed it in an envelope, which was opened only after the analysis of the results of each test subject.

The results not only confirmed the new method's compliance with the principles of the "Creative field" method, but also exceeded our expectations. The data obtained actually fully corresponded to our prognosis of the dynamics of IA (development or regression), made on the basis of the data obtained during the 1st stage.

We did not doubt the stability of M.G.'s data. He came on the first call, explaining that as a graduate student he can make use of his time as he finds best. According to the new method gave the same, the highest result. I made another prognosis about the results of A. B. His constant interest in the results of other guys made us worried. According to teachers, he is asserting himself because he lost the status of a leader in the classroom. Sadly, but the forecast 
was confirmed. His results decreased. His anxiety was also manifested in the fact that he did not immediately agree to participate in the second experiment.

"Five years later, when we found M. G., he was already a graduate student, he learned about our desire to repeat the experiment based on a new technique, and said with some humour: "I am now a theorist and I have a lot of time". On the first appointed day he came to the experiment, and demonstrated the same high level as five years ago, but now with the use of the another variant of the method".

Another student of the same class had a slightly different personality organisation in his school years. It seems that in the middle school, the not-quiteestablished character of this beautiful and very capable teenager has undergone a serious test of universal worship. But in high school he was "eclipsed" by other guys, and the self-centered "leader" began to form the egocentric complex, which, in particular, prevented him from reaching the highest level of results in the experiment. Each time discovering a new pattern, he inquired: "And what about the others?". The request to repeat the experiment did not meet his warm welcome: "I am now engaged in scientific work", - he said, - so I have no time (he, like M. G., got enrolled in graduate school). But after learning that the entire former class is involved, he agreed: "However, you may come and see me in my place for a while". During the experiment, he expressed the same concern: "Have others been tested by the new method? What are their results?". I predicted that there would be a regression in his results of the second experiment, and it turned out to be true.

An example of progress in the dynamics of giftedness we see in the work of G. M., who behaved inconsistently in the experiment at school (she was inhibited by self-doubt). In a situation of the University studies in her chosen major she had settled in her aspirations and abilities, and appeared to enter the heuristic level in a solid manner.

We have confirmed that the experiment shows well which of the subjects can become higher than the prestigious goals, whose cognitive interest becomes the leading motive, suppressing the side motives that we call "human weaknesses".

\section{The third stage of the experiment}

The opportunity for the third stage of the experiment appeared only a quarter of a century later, in 2002-2003. It was Important to find out how the impact of social change on the fate and identity of our participants (now academicians, professors in mathematics, physics, chemistry, business). The experiment was conducted on the basis of their institutions. The number of subjects decreased due to migration.

In general, we got the same result for the whole sample. The stability of this result for a quarter of a century speaks to its durability. However, in an era of social 
change non-assimilated system of values leads to a change of life orientations, leaving the science for the sake of higher salaries and so on. As a rule, it is also associated with the doubts about one's scientific mission. It is no accident that most of the participants with a stimuli-productive level work as teachers at universities, and only every sixth of them defended their theses.

On the contrary, heurists are more interested in their work. Many went to universities where it would be more interesting for them to study without thinking about their future careers and salaries. In this regard, a good example is F. D. "Professor, who invented a number of things for the development of science. He was in love with his topic and he was sure that by working in an elite Institute, he simply satisfied his interest".

"In the initial sample of girls who took part in the experiment, only two reached the heuristic level at the beginning of the experiment. They repeated it in the second round. M. M. is the "brain" of the laboratory in the Research Institute of the Russian Academy of education. E. K. is still the "star of the class". She was one of the first among her cohort to defend the doctorate. She is a good scientist, works successfully on topical issues at the research Institute, carrying out a number of foreign grants. G. M. reached the heuristic level after graduation. Currently, she is a well-known scientist in the field of medicine, who made an important discovery in the cardiology field".

M. G., who demonstrated the best results at the first stage, easily repeated the exit to the highest level and at our third meeting. Naturally, the data obtained in 2003 , as the results of the planned work of my laboratory, were to be published, and therefore all cannot be reproduced today in every detail. But in order to appreciate a young scientist's talent not with the help of numbers that fix the importance of correlations (which you understand, but you do not feel struck by), but with the help of emotional experience, it is necessary to compare it with the phenomenon of similar significance. It is impossible to evaluate scientific achievements without knowing this field of science. But we can understand their significance by comparing them with other achievements that we already have some idea of. We want to emphasize again that the longitudinal study we conducted with the aim of testing the prognosticality of the diagnostic method used, which was based on the developed theory of creativity. Therefore, we need the text of prominent physicist's review on the book written by M. G. 10 years after the graduate school on the topic of his dissertation, to be used as a "sentence". Let's limit ourselves to one of the excerpts from the review: "A lot of books have been written on theoretical Physics. There is a recognized example of such literature. This is the book of Landau and Lifshitz. It's not that this course consists of ten thick volumes - and it seems incredible that it could be written by two or three authors. And not even that the course covers all theoretical physics - nowadays 
there are no such universal experts in the world of theoretical physics. The reason that makes you admire this amazing accomplishment is the stunning beauty of the written. When the author began to write his book, Landau-Lifshitz did not yet have the chapter on the subject that is now included in it. And, however blasphemous it may sound, this chapter has something to compare... the author wrote a book, which is impossible to do without for any researcher in this field".

Later, I learned from his cohort mates that M. G. is a corresponding member of the USSR Academy of Sciences and that at the request of the staff he was chosen as the Director of the Institute.

\section{The fourth stage of the experiment}

The comparison of the data obtained earlier with the data obtained half a century later, as well as the analysis of the achievements of our subjects in different areas of their activities, allow us to make some judgements concerning the decisive role of life circumstances or, on the contrary, the decisive role of the individual's perseverance.

The central task of the fourth stage, of the ongoing longitudinal study is to analyze the role of the personality organisation in the manifestation of giftedness and check the prognosticality of the method of its detection.

"Half of the sample of heurists continues to work in the Institute, supporting their families with the money from overseas projects. More than half of the sample has a doctorate, and only one-seventh (those who work in firms) do not have a degree. One quarter of the sample works at Universities and only a tenth in firms".

Long-term observation of E. B. helps us understand that the decision to leave the University for the firm is not always associated with the dominance of material values, but with the complexity of society, the inability to protect the work which is a product of emotional investments and a number of year's work, because one is working in a closed system.

Asking M. G. for a meeting - at that point he already occupied the post of Director of the RAS Institute, I was sure that he had already long been an academician of RAS. That is why I didn't ask about it at the meeting. I learned that he was only a corresponding member from the Internet when I specified the list of his scientific problems. For him it is natural: the Director himself cannot nominate his candidacy. He once again convinced me in his natural modesty, when during the conversation I told him about the review of his book. He laughed: "Don't you say so, I wrote it as a young man, it should have been done in quite a different way". When I asked him questions related to his subject, he answered that there are many problems and the subject has become more complicated in connection 
with another kind of "soft matter", i.e. he has moved from the study of solids to the study of "living" matter. Then he initiated a shift in the conversation to the discussions of the issues that I am extremely interested in and that constitute his current concerns. I was shocked by the qualitative leap over the past 15 years in his development as a scientist - he did not only reached some progress in scientific issues, but also turned into a scientist thinking about the future of science. His observations on the further development of young people in science led to the conclusion that often students with brilliant abilities remain futile, and those who are persistently, constantly absorbed in their topic, come to discoveries. He concluded: "We should have not the teachers but scientists teaching at our Universities". As the Director of the leading Institute of RAS, he opened the department for the implementation of this system of training. One thing remains unclear: how can one combine successful solving of such a variety of issues in the field of theory, if not for the fact that illustrates its capabilities. He immediately formulated the problem in the very form it was presented to him only as far as in 1970, when he saw a blank testing sheet.

In a recent meeting, F. D. a respectable Professor of the Institute, told me about his work as an integral part of the work of the Institute, where new devices are designed, which allow him to discover new patterns, and cited as the reason why he loves being a part of the Institute. His face showed how much he cared about it. When I reminded him his words: "Top marks when you are interested and low marks when you are not", he laughed: "Sometimes I also got the lowest when I was interested".

T. B. was one of the first participants who immediately responded to my call. He solves a number of problems in a calm and modest way, and in the same manner he talks about his progress in science. He is not quick to say that he has not only defended his doctorate and works as a Professor at leading universities and institutes of the Academy of Sciences. He does not look like the hero of the anniversary, the recording of which I received from his friends on the Internet. The path to becoming a hero was not easy. Being a "star" of his class, he was not immediately admitted to the MSU. In the ' 90 s he tried to work abroad but soon returned. He graduated from the graduate school of Moscow State University in 2003 and defended the candidate's thesis. The fact that today he is among the leading mathematicians of the world, those few scientists whose works shape the contemporary theory of modalities, is an evidence and an example of considerable courage and great love for science.

The meeting with R. K. took place at her workplace at the Institute. Our attempt to see her at the third stage of experiment - she was a doctor of physical and mathematical sciences and a busy person - failed: regular business trips and children's ailments prevented her from seeing us. She does not remember the 
formulation of the first stage's problem, she finds the solutions slowly, drawing the line, and it takes her time. Sometimes it takes a few minutes. However, she shows her professionalism in Math in the analysis of provocative arrangements of a problem. Young men keep entering the rom, and I dared to ask her about the nature of her work in this Institute. She emphasizes the administrative aspect of the work, but notes that it is interesting because it is associated with mathematics, and she experiences moments of joy being here, because mathematics is the science of beauty.

The time of our visit was limited and I asked her to write something about it briefly. This woman is 64 years old and she recently lost an adult daughter. But only by reading the entire text can we understand what "commitment" to one's field is and why both such individuals and their creativity are evolving. "What is it where the beauty of mathematics reveals itself? It lies in simple solutions to difficult problems, in establishing unexpected connections, but the main thing is that the essence of things is revealed. I would say that mathematicians, like Pasternak said, "want to get to the bottom of the matters"... I must say that the feelings that I experience in my professional activity remain exactly the same as they were in childhood when I was solving problems in the books. Quite often it happens that I read someone's article and I more or less understand the formal form of what is written in it, but I do not understand the essence. I have a question then about what is really going on there. This question in my head "itching". I want to understand it, and I probably feel subconsciously that I can understand it. I ask questions to other people, I think, I look at examples, I can count something. And then something clicks in my head, and everything falls into place. And at this moment I want to say to myself: "Yes, I'm good. I succeeded". So, recently my colleague sent me an article in which he and his students described two procedures for obtaining objects of one nature from objects of another nature. And I once thought that it was very similar to two procedures from a completely different area.

However, in that field these two procedures gave all the objects of the second nature. Then I thought that maybe here, too, these procedures resulted in all the objects of the second nature. Then I began to think how it could be proved. And, in the end, I managed to prove it. And I was very happy about it.

It should be noted that all participants of the experiment mentioned the beauty of mathematics. Thus, E. B., whose life path abruptly changed its direction in the direction due to his temperament, argued that whatever he did in his life, mathematics was always in the background, because mathematics is beauty. Currently, he writes stories and is passionate about poetry: "It is impossible to explain the experience of beauty - how to convey harmony? How to convey the feeling of the beauty of one's beloved girlfriend? A goal scored? Gaudi's 
buildings? I cannot say that it started with the 7th grade, but as early as when I was in school, at the sight of solving problems, I was proud of humanity who were able to create such an unexpected beauty. Something similar occurs in the reading of poetry. Like poetry, mathematics is a virtual reality, a departure from everyday reality, an opportunity to go into the world of absolute incorporeal and intangible harmony".

$\mathrm{H}$. Selye astutely pointed out that the determinants of becoming a scientist are curiosity and admiration for the beauty of patterns [30].

We see how the values that are the product of being a part of a particular school culture are a determining factor in the development of the individuals throughout their lives, and become stored as an unconscious understanding of importance of these values: "No one has changed in our class".

Fifteen-year interval in the 4th stage of the experiment allowed to identify qualitative jumps in the personal and professional development of our subjects. The expansion of the sphere of professional realization took place, first of all, in those subjects who belonged to the heuristic and creative levels in 1970.

\section{Conclusion}

Our understanding of creativity is related to the personality organization, the formation of which depends on the influence of life circumstances that affect its development or deformation. It determined the acmeological aspect of ongoing research. Let us emphasize that the longitudinal nature of the study to a greater extent allows to identify the personality organization which ensures its stability in different not only life, everyday, but also different social conditions.

The analysis of the life path and scientific achievements of our subjects proved the prognosis we composed at the beginning of this path. The definition of the highest form of creativity based on the ability to develop activities on one's own initiative, allows one to scientifically explain such discoveries, where the action loses its form of response. An example of this is "porism" as an unexpected exit to the "unbidden", which was observed by the ancient Greeks. And also an unexpected the discovery of a new fact, not being in search of an answer to the already posed problem, as J. Hadamard pointed out [31]. In this study, we found that the results obtained in the experiment not only received confirmation in the professional activities of our subjects, but also coincided with the nature and level of their professional achievements with the style of work in the experiment. This is very clearly demonstrated by the discovery of one of the most striking heurists - F. D., - where the regularities he discovered in his scientific field correspond to the level of regularities discovered in the experimental material. 


\section{References}

1. Bogoyavlenskaya D. B., Bogoyavlenskaya M. E. Odarennost': priroda i diagnostika [Giftedness: Nature and diagnostics]. Moscow, Obrazovanie lichnosti Publ., 2018. 240 p.

2. Bogoyavlenskaya D. B. Creativity and giftedness concepts once again: A methodological approach. In: L. I. Larionova, A. I. Savenkov (eds.) Psikhologiya odarennosti i tvorchestva [Psychology of giftedness and creativity]. Moscow, Nestor-Istoriya Publ., 2017, pp. 21-36.

3. Bogoyavlenskaya D. B., Shadrikov V. D. (eds.) Rabochaya kontseptsiya odarennosti [Working concept of giftedness]. Moscow, 2003. 94 p.

4. Bogoyavlenskaya D. B. The nature of creativity without mysticism. In: Filosofiya tvorchestva [Philosophy of creativity]. Moscow, RAS Institute of Philosophy Publ., 2015, pp. 116-134.

5. Bogoyavlenskaya D. B. Psikhologiya tvorcheskikh sposobnostei [Psychology of creative abilities]. Samara, Izdatel'skii dom Fedorov Publ., 2009. 416 p.

6. Vygotskii L. S. Myshlenie irech': psikhologicheskie issledovaniya [Thinking and speech: Psychological investigations]. Moscow, Natsional'noe obrazovanie Publ., 2016. 368 p.

7. Susokolova I. A. An experience of a psychogenetic study of intellectual activity. Voprosy psikhologii, 1985, no. 3, pp. 154-158 (in Russian).

8. Bogoyavlenskaya D. B., Zhukova E. S. Longitudinal study of the development of creative abilities during junior and early adolescence. Obrazovanie lichnosti - Personality Formation, 2017, no. 3, pp. 80-89 (in Russian).

9. Zhukova E. S. Longityudnoe issledovanie tvorcheskikh sposobnostei [Longitudinal study of creative abilities]. Materialy VI S"ezda RPO [Proc. the 6th Congress of the RPO]. Kazan, 2017, Vol. 2, pp. 268-270.

10. Zhukova E. S. Longityudnoe issledovanie stanovleniya tvorcheskoi lichnosti [A longitudinal study of the development of creative personality]. Materialy Mezhdunarodnoi nauchnoi konferentsii: Vospitanie i razvitie lichnosti [Proc. the International Scientific Conference "Education and development of personality"]. Moscow, IRL RAO Publ., 1997, pp. 55-57.

11. Banzelyuk E. I. Pokazateli kreativnosti $i$ ikh dinamika [Indicators of creativity and their dynamics]. Diss. Cand. Sci. (Psych.). Moscow, 2008. 213 p.

12. Banzelyuk E. I. Age dynamics in creativity indicators. Voprosy psikhologii, 2008, no. 3, pp. 55-61 (in Russian).

13. Danyushevskaya T. I., Bogoyavlenskaya M. E. Studying the dynamics of development of creative abilities. In: Ezhegodnik Rossiiskogo psikhologicheskogo obshchestva: Psikhologiya segodnya [Yearbook of the Russian psychological society: Psychology today]. Moscow, 1996, Vol. 2, Issue 1, pp. 139-140. 
14. Subotnik R. F., Arnold K. D. (ed.). Beyond Terman: Contemporary longitudinal studies of giftedness and talent. Greenwood Publishing Group, 1994. 461 p.

15. Terman L. M., Oden L. N. The gifted group at mid-life: 35 years follow up of a superior child. Genetic studies of genius, 1959, Vol. V. Stanford (CA): Stanford University Press. 950 p.

16. Torrance E. P. Growing Up Creatively Gifted: A 22-Year Longitudinal Study. Creative child and adult quarterly,1980, no. 3, pp. 148-158.

17. Torrance E. P. The beyonders in a thirty-year longitudinal study of creative achievement. Roeper review, 1993, no. 3, pp. 131-135.

18. Benbow C. P., Arjmand O. Predictors of high academic achievement in mathematics and science by mathematically talented students: A longitudinal study. Journal of Educational Psychology, 1990, no. 3, pp. 430-441.

19. Perleth C., Heller K. A. The Munich longitudinal study of giftedness. In: R. F. Subotnik \& K. D. Arnold (eds.), Beyond Terman: Contemporary longitudinal studies of giftedness and talent (pp. 77-114). Norwood, NJ: Ablex, 1994.

20. Runco M. A. A longitudinal study of exceptional giftedness and creativity. Creativity Research Journal, 1999, no. 2, pp. 161-164.

21. Gottfried A. W., Gottfried A. E., Guerin D. W. The Fullerton Longitudinal Study: A long-term investigation of intellectual and motivational giftedness. Journal for the Education of the Gifted, 2006. Vol. 29. no. 4, pp. 430-450.

22. Wai J., Lubinski D., Benbow C. P. Creativity and Occupational Accomplishments Among Intellectually Precocious Youths: An Age 13 to Age 33 Longitudinal Study. Journal of Educational Psychology, 2005, no. 3, pp. 484-492.

23. Wai J., Lubinski D., Benbow C. Pl. Accomplishment in science, technology, engineering, and mathematics (STEM) and its relation to STEM educational dose: A 25-year longitudinal study. Journal of Educational Psychology, 2010, no. 4, pp. 860-871.

24. Heller K. A. The nature and development of giftedness: A longitudinal study. European journal for high ability, 1991, no. 2, pp. 174-188.

25. Perleth C., Sierwald W., Heller K. A. Selected results of the Munich longitudinal study of giftedness: The multidimensional/typological giftedness model. Roeper Review, 1993, no. 3, pp. 149-155.

26. Bogoyavlenskaya D. B. Subject and method of research on creative abilities. Psikhologicheskii zhurnal, 1995, no. 5, pp. 49-58 (in Russian).

27. Kalmykova Z. I. Produktivnoe myshlenie kak osnova obuchaemosti [Productive thinking as a basis for learning]. Moscow, 1981. $200 \mathrm{p}$. 